Healthy Cities: The Impact of Food Retail-led Regeneration on Food Access, Choice and Retail Structure

Steven Cummins, Anne Findlay, Mark Petticrew, Leigh Sparks

Published in:

Built Environment, volume 31, issue 4 Planning Healthy Towns and Cities, Winter 2005, pages: 288-301

http://dx.doi.org/10.2148/benv.2005.31.4.288 


\section{Healthy Cities?: the impact of food retail led regeneration on food access, choice and retail structure}

Cummins $\mathrm{S}^{1}$, Findlay $\mathrm{A}^{2}$, Petticrew $\mathrm{M}^{3}$ and $\mathrm{L}$ Sparks ${ }^{2}$

${ }^{1}$ Department of Geography, Queen Mary, University of London, Mile End Road, London E1 4NS

${ }^{2}$ Institute for Retail Studies, University of Stirling, Stirling FK9 4LA

${ }^{3}$ MRC Social and Public Health Sciences Unit, University of Glasgow, Glasgow G12 8RZ

Anne Findlay is the corresponding author. Telephone (01786) 467398, Fax (01786) 465290, Email: a.m.findlay@stir.ac.uk

April 2005 


\title{
Healthy Cities?: the impact of food retail led regeneration on food access, choice and retail structure
}

\begin{abstract}
The health, social and planning policy agendas which have focused on the issue of food deserts, food access and food choice provide the context for this study of the outcomes of a large scale food retail intervention in Springburn, Glasgow.

Through an analysis of changing retail structure and foodscape health impacts on food provision, food choice and physical and economic accessibility. This is set within the regeneration context of the Tesco St Rollox Partnership. Conclusions are reached on the potential for such schemes to deliver a range of diet, health, social, regeneration and planning policy goals.
\end{abstract}

Keywords: Regeneration, food retailing, Glasgow, food deserts, accessibility, impact. 


\section{Healthy Cities?: the impact of food retail led regeneration on food access, choice and retail structure}

Combating social exclusion and building healthy communities are central tenets of the UK Government’s ‘joined-up’ strategy to improve public health and reduce health inequalities (Department of Health 1999a, Wanless 2004). Achieving these aims partly involves ensuring communities have good access to affordable food (Department of Health 1999b) as a component of a suite of recommendations for dietary change focused on awareness, affordability and acceptability (Department of Health 2003).

The term 'food-deserts' has been coined to describe poorer areas where communities have little access to an affordable and healthy diet (Cummins and Macintyre 2002a). Both the existence of food deserts and their impact on population health are controversial. For some they are 'factoids' or assumptions reported and repeated until they are considered true (Cummins and Macintyre 2002a) and an example of 'policy development running significantly ahead of systematic evidence-based research’ (Wrigley et al 2003b). For others, the existence of food deserts is undeniable (Furey et al 2001, Kayani 2003) and reflects a long-term failure to ensure food equity for all of the UK's population (Lang and Caraher 1998, Donkin et al 19999, 2000, Tingay et al 2003). The recent UK White Paper on Public Health (Department of Health 2004) speaks of actions to 'secure better access to healthier choices for people in disadvantaged groups or areas', noting that 'deprived communities often lack good local access to places to buy fresh fruit and vegetables’. Policies to combat dietrelated health inequalities have therefore been a priority (Acheson 1998, Department 
of Health 1999a,b, Wanless 2004) but evidence informing where, when and how to reduce these inequalities is only now emerging (Wrigley et al 2003a, White et al 2004, Cummins et al 2004).

Furey et al (2001) note that: "Food deserts ... have been further exacerbated by the effect of large grocery retailers locating on the periphery of towns and the subsequent displacement effect of independent retailers in the town centre” (p.447). The development of food superstores and associated retail concentration and locational decentralisation (Burt and Sparks 2003) apparently left some areas with only limited access to affordable and healthy food (Cummins and Macintyre, 1999, 2002b, Lang and Caraher 1998, Caraher et al 1998, Clarke et al 2002, Rex and Blair 2003, Guy and David 2004). Cummins and Macintyre (2002a) comment: 'Popularly therefore, the major food retailers are held partly responsible for the emergence of food deserts - for not establishing shops in poor communities and so denying residents the benefits of choice and a good price' (p436). The Competition Commission however found that "there is no systematic link between the locational strategies of supermarket operators and restricted access to groceries” (2000, Vol 2, p.314). White et al's (2004) recent call to dispense with the tag of 'food desert' arises in part from such contradictory claims (see also the special issues of Urban Studies 2002 and International Journal of Retail and Distribution Management 2004). They suggested that a 'food desert' only actually existed for certain groups limited to shops within their immediate locality. This paper concurs with that view. There are areas, however, with differential access to food retailing and areas where retail provision needs modernisation (Carley et al 2000). The paper is concerned with an area where sub localities have such restricted 
access and where there has been a lack of development and modernisation of retail provision.

Concerns about food access, healthy food choices, social exclusion and improving general health came together in policy statements and actions in the late 1990s (see Cummins and Macintyre 2002a, Wrigley, Guy and Lowe 2002). In particular the Department of Health Policy Action Team on Shops focused on improvements to the local food retail economy. They had in mind mainly local community efforts to improve local control and provision and to generate local initiatives (Social Exclusion Unit 1998, 2000). However, leading retailers also recognised that there were development opportunities for them, particularly if they could position their stores as 'regeneration’ investments for deprived communities (Guy 2002, 2004). Retailers argued that not only would such stores provide better access to food in such areas (and thus affect diet and health), but that they could also act as a catalyst for economic development and enhance local employment skills. There appeared to be a coming together of diverse agendas and objectives which could be met from large scale retail interventions in deprived areas. The ways in which large scale retail interventions contribute to regeneration often depends, as in the case of regional development initiatives, on the relational context in which they are operating (Yeung 2005). The policy objectives and agencies involved therefore are diverse, as are the literatures on which these policies draw.

Of the large food retailers in the UK, Tesco was particularly active in engaging with the food desert and 'regeneration'/social inclusion agenda. Tesco obtained planning permissions for 'regeneration' stores as promoting the benefits to local communities 
(Tesco Stores 2002a, 2002b). The Tesco Regeneration Partnerships (Tesco Stores 2002b) developed new stores in deprived communities through linking with local organisations to identify and reclaim sites and by ensuring training and guaranteed employment for local residents (often focusing on the long-term unemployed), thus enhancing and regenerating the area. For a major retailer, investing in deprived areas brings new opportunities in the otherwise restricted planning environment for large new store development (Wrigley 2002, Wrigley, Guy and Lowe 2002). In Tesco terms 'the strict planning environment means that we are encouraged to go places other businesses wouldn't' and that whilst Tesco in regeneration areas 'can't change the world...we can be an important catalyst' (Grocer 2001).

The health impacts of large scale retail interventions and regeneration are likely to come through improvements in food access and choice, but these have been little studied to date and the existing empirical research is equivocal. Clarke et al (2004), in the context of a Tesco regeneration hypermarket in Leeds, comment that "we would be very surprised if the opening of such a new Tesco hypermarket did not have substantive and discernable effects, as is normally the case, on other food stores in the area, large and small” (p.92). However they do not spell out either the direction or magnitude of such impacts. Wrigley et al's (2002) study of that same store made general points about ‘cannibalisation’ of trade from other Tesco stores. The suggestion is that in terms of retail structure the impacts of large scale retail interventions may be negative (Guy and Duckett 2003). This would imply shop closures and a redistribution towards the new facility rather than a widening of food choice and accessibility. Guy (Guy et al 2004, Guy and David 2004), shows from 
research on Cardiff how difficult it is to ascribe causality at a time of long-running and/or general retail change.

The Tesco St Rollox Partnership in Springburn, Glasgow was launched in November 1999 with the aim of creating a better place to live and work. Tesco led the Partnership, working with other employers, unions, the local community and public agencies including North Glasgow College. The strategy focused on putting employability training at the heart of the regeneration initiatives, through skills training for local long-term unemployed and guaranteed jobs in the new Tesco Extra hypermarket at the end of the training period (Tesco Stores 2002c).

The research reported here is one strand of a larger study that evaluated the impact of a non-healthcare (i.e. hypermarket) intervention on health and diet (Cummins et al 2004). Results on the impact of the intervention store on diet and psychological health are reported elsewhere (Cummins et al 2005a, 2005b). Briefly, the study focussed on evaluating the impacts on food access in a low-income area because it had previously been suggested that this might improve the opportunities of residents to make healthy food choices, reduce social exclusion, and ultimately may improve general health and reduce diet-related health inequalities. The evaluation carried out in Leeds (Wrigley, 2002) did in fact report such an effect, with the mean daily consumption of fruit and vegetables increasing by about 0.44 portions per day, though the absence of a control group in this study meant that it was difficult to be sure whether that change was due to the new store, or to some other factor. For this reason we adopted a controlled study design, and in contrast, found little evidence of an overall effect of the new store on fruit and vegetable consumption; although there was some small 
improvement in diet in the intervention area, there was a similar improvement observed in the comparison area. Data on the impacts of the store on retail provision have not previously been presented. The study methodology is described in more detail below. The retail structures of the areas involved are then examined and retail survey results analysed in relation to the key questions outlined above. In this paper a set of questions on the regeneration effects of a major food retail-led scheme in bringing change to a disadvantaged part of Glasgow, with limited food retail provision, are identified. The questions for which evidence may be sought are:

1. Do large retail stores impact positively or negatively on the existing retail structure?

2. Do large retail stores increase or merely redistribute retail provision? Do they represent improved food choice?

3. Do large retail stores result in improved physical and economic access to food including fresh fruit and vegetables?

4. Do large stores act as catalysts in regeneration, providing new jobs and spin off regeneration effects?

[Figure 1 about here]

\section{Methodology}

Unlike other studies this project used a comparison (or control) area (Shettleston) to ensure that trends in the intervention area were not merely symptomatic of broader more general trends (Figure 1). This proved critical in interpreting both diet and health issues (Cummins et al. 2005b). It is equally important in examining the 
regeneration impacts of retail investment on the built environment and urban economy.

Intervention (Springburn) and comparison (Shettleston) areas were matched by area level of deprivation (Carstairs-Morris DEPCAT), with each area having a DEPCAT of 7 (a score of 1 represents the most affluent and 7 represents the most deprived). Springburn and Shettleston have often been bracketed as the two most deprived and unhealthy constituencies in the UK (Scotland on Sunday 2002). Recent data from NHS Health Scotland confirm that these two areas are amongst the most deprived in Scotland (NHS Health Scotland 2004). They have a high prevalence of smoking (about 50\% in both areas), an average income of about one-third below the Scottish average, low levels of fruit and vegetable consumption (about a third eat fruit daily) and high levels of ill-health (about 30\% with limiting long-standing illness). Male life expectancy fell in both areas between 1991-2001 and is only 63.9 years in Shettleston and 66.6 in Springburn (Scotland average 73.3).

To consider impacts on retail structure, data on location, line of business and trading name were collected. The data collected provide a broad description of the retail structure thus answering the key questions.

The retail structure methodology followed three steps:

- Delineation of the boundaries of the communities;

- Initial (pre-intervention) survey work in October 2001 to 'map' the retail structure (shop locations shown in Figures 2 and 3). This involved driving and walking all streets in the survey areas and recording and plotting the store data; 
- $\quad$ Repeat (post-intervention) surveys on 6-monthly intervals to assess change (May 2002-Oct 2004).

In addition to the shop surveys household questionnaire surveys before the opening of Tesco (2001) in Springburn and a year later (2002) were carried out in both areas. A total of 3975 questionnaires were administered to households within $1 \mathrm{~km}$ of the main shopping areas. The first wave of the survey was carried out in October 2001 and respondents followed up the following year. This permitted changes in shopping behaviour by respondents to be studied giving insights into which shoppers switched to Tesco in Springburn. The surveys investigated shopping behaviour, diet, health and background household characteristics (see Cummins et al 2004, 2005b).

[Figures 2 and 3 about here]

\section{The Retail Structure of Springburn and Shettleston: streetscape and foodscape}

In retail terms, both communities historically comprised traditional Glasgow tenement streets with shops on the ground floor of properties. Long linear streets dominated the pattern with retailing concentrated along Shettleston Road and Springburn Road respectively. Multiple and independent retailers (food and non-food) located in this streetscape and drew neighbourhood consumers as well as those from further afield. Whilst flux and change in the numbers and types of shops occurred throughout the $20^{\text {th }}$ century, until the late 1970 s, the streetscape and shopping patterns in both areas would be identifiably similar. 
In the 1970s the street pattern in Springburn was realigned and redeveloped as part of city-wide transport plans. Road realignment in Springburn was compounded by further planner-led change to the retail structure. Pacione (1982) notes that by 1981, “Springburn’s position in the urban retailing system had slipped to local significance, largely due to the morphological and organisational deficiencies of the area but also as a result of the local authority's decision to concentrate shopping activity within a well defined area adjacent to Springburn Hill in order to provide land for new road building and facilitate the demolition of sub-standard properties” (p.168). Springburn 'gained' a new small shopping centre anchored by a small Presto supermarket and with a number of smaller shops. This centre, of which only Phase I was built and opened (October 1981) was intended as a community hub with other services and office development.

The 1992 review of shopping policy in Glasgow identified both Springburn and Shettleston as 'deficit areas' in terms of convenience shopping provision. Shettleston had an estimated £8m convenience retail deficit and Springburn £17.7m (Glasgow City Council 1992). In both cases specific sites were identified for development. In Springburn the area adjacent to the Springburn Shopping Centre was given planning permission for a foodstore as part of Phase II of the Springburn Centre, but this was not then developed. Instead, planners permitted the St Rollox site (a former BR railway engineering works), originally earmarked for non-food development was given planning permission for a foodstore as well. Following some planning negotiation this became the Tesco Extra hypermarket site. It is less geographically central to Springburn than was the site originally desired by the planners (Figure 2). In Shettleston a centrally-located but long derelict former glassworks site was 
scheduled as a food store. Tesco applied for planning permission for a hypermarket here but this was refused after local objections. Tesco eventually opened a smaller supermarket at the site in August 2003.

Food Provision and Choice: Changes in Retail Structure

The 2001 Census of Population shows that the populations of Springburn and Shettleston are of comparable size (32,323 for Springburn and 28,779 for Shettleston). Despite this, the initial survey showed that Shettleston had more shop units than Springburn and thus a higher number of shops per thousand population. However an analysis of the broad lines of business shows that the proportions in the main retail categories are comparable between the two communities (Table 1).

In October 2001 Springburn had a retail stock of 186 units although not all of these were in retail use (as defined by ONS). Many were in the service sector including, for example, fast food outlets. Shettleston had a retail stock of 293 units. The size of the majority of these units was less than 1000 square feet. Smaller grocery units often stocked basic fruits and vegetables but often these were of poor quality and the condition of the shop was also poor by comparison with modern retail facilities.

[Table 1 about here]

In terms of larger scale food retailing, Springburn, prior to the opening of the hypermarket, had a small Safeway (formerly Presto) supermarket in the Springburn Shopping Centre. A discount store (Lidl) is adjacent to the new Tesco hypermarket. Many Springburn residents shopped outside Springburn travelling to Asda in Robroyston, Somerfield on the edge of Bishopbriggs or stores near to their work. 
Shettleston is similarly provided for with a small co-operative supermarket in Shettleston Road, the main shopping street. As in Springburn many shoppers frequent stores further afield including Asda at Parkhead Forge (itself subject to previous regeneration attempts - Donnison and Middleton 1987, Glasgow City Council and Strathclyde Regional Council 1993). Shopping at more distant locations is a confirmation of the limitations of local facilities. Due to access problems however a significant proportion of residents do not have this 'choice’. Beyond these large stores, food shopping is mainly provided by dispersed local convenience outlets or small parades (Figures 2 and 3).

[Table 2 about here]

Table 2 considers the impact of the development of the Springburn hypermarket on the retail structure. Whilst the survey work in the area has continued (the most recent survey was in may 2005), Tesco opened a supermarket in Shettleston in August 2003. As such May 2003 is used in table 1 as the cut off date for the comparative data. Comparisons beyond this begin to experience problems of an altered control area. The table monitors changes in Springburn as well as providing a check on differences and similarities between the two areas.

In terms of the vitality of the retail property market it can be seen that the retail sector in Springburn saw a substantial proportional reduction in vacant units and a lowered vacancy rate. Comparison with Shettleston suggests that this was not a general trend but that Springburn experienced a more dramatic improvement in property take up. Significantly the decrease in vacancies in Springburn was particularly in the outlying 
parts of the area. Vacant prime sites in the centre of Springburn are very limited. Turnover also declined suggesting some stability in the market. Of the units vacant in October 2004, 46\% in Springburn and $42 \%$ in Shettleston had been continuously vacant since at least the first survey in October 2001. A high proportion of retail stock remaining vacant in both areas is in poor condition and several properties are unlikely ever to be filled. Indeed several properties in Shettleston have subsequently been demolished.

The direction of change by type of retailing over the survey period has been the same in both communities, with the exception of comparison goods retailers, where there has been a decline in Shettleston but an increase in Springburn (Table 2). This offers Springburn improved shopping status. Service units rise in proportion over the surveys from 2001 to 2004. This is a general trend. Existing outlets selling food and fresh foods have not changed as much as might have been expected in Springburn. By October 2004 there was a net loss of three convenience outlets in Springburn since the opening of Tesco. The locations reflected factors such as the demolition of surrounding housing. This has been compensated for by the enlargement and refurbishment of several other food units. In both areas there was a decline in butchers by 2004 but this a more general trend. Overall Tesco seems likely to have added to rather than reduced food choice and the availability of fruit and vegetables in the area.

\section{Accessibility}

In terms of physical and economic access survey results from the household survey data for Springburn are instructive. Some 30\% of the survey households switched to the new Tesco in Springburn. In the time period concerned this represents a 
significant level of switching (East et al. 2000). Some 69\% of shoppers who switched to Tesco in Springburn were in households with a weekly disposable income of less than $£ 100$ and the mean household disposable income of switchers was $£ 121.33$. This indicates that Tesco provided an economically accessible option for shoppers from Springburn. Shopping patterns indicate that the store has had its most important impact on those living in postcodes G21_1 and G21_4. These encompass the 500m area around the store immediately to the north of the railway line. This is in line with the findings of other comparable research (Rex and Blair, 2003). G21_1 had very poor shop provision previously so a demonstrable improvement in access has been achieved. Indeed some 39\% of shoppers reach the store by walking, a figure higher than that for Springburn as a whole. Similar results were obtained by Whelan et al. (2002). There has been a particular decrease in reliance on the use of a 'friend's car' indicating greater independence of shopping. Again Whelan et al. (2002) emphasised a similar finding stating that independent physical access is vital to self-esteem. Exchange of favours, in public health terms, can, however, be an indicator of social capital and a healthy area so this may not be an entirely positive effect. There are variations in patronage within the area which are distance-related but, which also undoubtedly reflect the ways in which different parts of Springburn associate or disassociate with each other and in which shopping identities are articulated.

There was little evidence from this part of the study of an effect on either mean vegetable consumption, or mean fruit and vegetable consumption, and although there was some small improvement in self-reported diet in the intervention area, there was a similar improvement in the comparison area. About one-third of those living in the area where the new store was built reported switching their main food shopping to the 
new store. They also reported a small increase in fruit and vegetable consumption of about 0.35 portions of fruit or vegetables per day. However this increase was not statistically significant. The hypermarket therefore did not appear to have significant effects on the diet of the local community (further details are reported in Cummins et al. 2005a). This suggests that the problem of improving diet in poorer communities is not simply tackled by the relocation and redevelopment of food stores in poorer areas. While this may increase access to a healthy diet through the expansion of fruit and vegetables provision, access to less healthy foods (ready meals, highly preserved foods, drinks such as Sunny Delight (Cummins et al. 2005b) as well as tobacco and alcohol) may also be considerably enhanced. Improving food access alone, without improving knowledge of healthy eating, may even in the long run have negative effects on diet.

\section{Regeneration Impacts}

The two communities (intervention and comparison) were selected on the basis of similar, high levels of deprivation and initial retail provision. Despite some differences in the physical retail structures through redevelopment, the two communities had broadly comparable retail structures by line of business (Table 1) and at the outset of the study similar overall vacancy rates (Figure 4).

[Figure 4 about here]

The proportion of vacant units (which is a key vitality and viability measure) has fallen in both communities although the timing of the changes differed. The absolute number of vacant units at October 2001 was higher in Shettleston, but proportionally 
by business line the positions in Shettleston and Springburn were identical (Figure 4). Post-intervention the proportions diverged quite strongly. Initially, there was a decline in vacancies in both areas, but this was not maintained in Shettleston where the vacancy rate rose considerably in October 2002 and May 2003, ahead of the opening of the Shettleston Tesco store but as in Springburn declined after the Tesco store opened.

The employment goals of the Tesco St Rollox Partnership appear to have been met (Tesco Stores 2002c) and it would seem that the regeneration is a success in these terms. In addition to improved self respect the employment of local people, which was crucial to the terms of the partnership scheme, has the potential for the store to be more deeply embedded in the community. Income effects may also be expected to assist regeneration and self esteem of the area and to allow more individuals more (healthy) choices. Furthermore, NOMIS data on employment show that between 2000 and 2003 there has been a 25\% increase in retail sector jobs in Springburn and that not all these have been associated with the Tesco development itself. Outside the retail sector there have been other regeneration initiatives in Springburn, with older council owned housing being demolished, new houses built and two new secondary school buildings.

By drawing into Springburn a major national retail company the relational links with other areas have been increased and new external expertise infused into the community. There has been clawback of retail customers to the area from Asda Robroyston and several other stores causing some redistribution of spending, but this is not redistribution of spending within Springburn but redistribution within the wider 
retail structure. From the perspective of Springburn it serves to enhance local use of Springburn increasing retail spend within the area. The new hypermarket not only attracts local shoppers but anticipates increasing use by customers from further afield, probably especially for purchasing non-food items. Indeed the Tesco St Rollox Partnership always intended that the store would draw trade both from within the area and but also from the suburbs of north-east of Glasgow.

Few local organisations could have made the same employment impact. Given the local recruitment policy this is an impact which in itself increased local spending power. This is one reason why the Policy Action Team on Shops model of small scale local initiatives offered a more limited regeneration prospect. Given the significance of purchasing in superstores and hypermarkets by residents in areas such as Springburn, even if it means going out of the area, it is unlikely that such initiatives could have achieved any greater diet benefits or delivered equivalent levels of choice and access in the case of Springburn. It is also the case that the existence of Tesco provides a stimulus to the other new housing development due to the changing perception of the area's facilities, housing which is critical to the viability of Tesco itself.

The opening of the Springburn Tesco hypermarket therefore appears to have impacted positively on the overall retail structure of Springburn. The retail property market seems to have adjusted, becoming stronger rather than weaker, which suggests a possible overall area improvement. To that extent, retail regeneration in an area of retail deficit may have had a positive effect (Dobie 2004). 
[Table 3 about here]

Table 3 summarises the findings from the research within the context of the policy debates identified earlier. In terms of goals and objectives it can be seen that in the case of Springburn many of the policy objectives, but not all, were met. The policy objectives in terms of health and the built environment have been easier to meet through the place-based initiative of large scale retail regeneration than the more specific diet objectives.

\section{Conclusions}

There have been many studies of shopping impact and trade diversion and it is widely argued that the impact of large new stores has had a damaging effect on high streets and proximate small scale local retailing. In this case the hypermarket was developed as part of a regeneration initiative in a deprived and 'under-served' community and the intention of the developers and the planners was that by such significant investment the area as a whole would gain benefits and thus 'regenerate'. The design of this study sought to identify the extent to which the built retail structure, foodscape and overall health of the area did change after the opening of the new store and whether, through the use of a comparison community without such an intervention, such changes could be ascribed to the intervention or 'regeneration' store.

In terms of the built environment the large scale retail initiative is likely to have been positive providing not just improved food provision, but improved food choice, increased physical and economic accessibility and wider regeneration effects. Our 
findings challenge the widespread assumption that the opening of a hypermarket always has an immediate and deleterious effect on the retail structure of an area. The opposite is found, with mainly positive effects realised in the three years after opening. The research also suggests that there is considerable site specificity about impacts. The historical morphology of the area, the shape and use of the retail structure itself, the age and fitness of the retail units and population movements in and out of the area, all condition the impact of a new development. Simple quantitative floorspace modelling, as often used in formal impact studies, does not capture these effects. Arguably better food provision, choice and accessibility are necessary prerequisites to other improvements in diet and health and may not themselves be achieved through place based initiatives alone. Identification of necessary and sufficient conditions for achieving particular outcomes remains elusive but a challenge to planners.

Achieving improvement in health and diet is a complex task, and small changes in diet may be less important that other social changes a major new store may bring. For example, the Springburn hypermarket adds new jobs to an area in need of jobs; new employment opportunities may have greater health impacts on an area than a new store. It may offer opportunities for physical activity - there is evidence of increased walking to the store and more independence in reaching the store than formerly. However this has to be balanced against potential negative impacts; for example, improvements in retail access could in theory increase access to an unhealthy diet. The new hypermarket has broadened choice but people also need to be empowered to make the 'right' choices. 
Within the broader research context the paper expresses the need to engage with the ways in which particular developments will impact differentially in different urban contexts in order to assess which scale of development and which site will most improve food choice and food access without compromising existing provision or choice. Indeed it seems that any redistributive effects will not impact negatively on existing local food choice within Springburn but on broader shopping patterns outside Springburn through clawback. Similarly, whether the Tesco St Rollox Partnership can sustain the current impetus in Springburn, and provide a basis for other regeneration projects and health initiatives, will not depend on its success within Springburn. Instead it will rest on the retail development's 'relational' success in attracting sufficient custom from outside Springburn and the perception of the area as a better place to shop and live as a result of the regeneration initiative. 


\section{Acknowledgements}

The research for this paper was undertaken by the authors through a grant from the Department of Health Reducing Health Inequalities Initiative (ref 121/7492). The views expressed here are those of the authors and not necessarily those of the Department of Health. Steven Cummins is supported by a MRC Special Training Fellowship in Health of the Public. Mark Petticrew is funded by the Chief Scientist Office of the Scottish Executive Department of Health. 


\section{References}

Acheson D. (1998) Independent inquiry into inequalities in health. London: The Stationary Office.

Burt, S.L. and L. Sparks (2003) Power and Competition in the UK Retail Grocery Market. British Journal of Management, 14: 237-254.

Caraher M., Dixon P., Lang T. and Carr-Hill R. (1998) Access to healthy foods: Part I. Barriers to accessing healthy foods: differentials by gender, social class, income and mode of transport. Health Education Journal, 57: 191-201.

Carley, M., Kirk, K. and McIntosh, S. (2000) Retailing, sustainability and neighbourhood regeneration. York: Joseph Rowntree Foundation.

Clarke, G., Eyre, H. and Guy, C. (2002) Deriving indicators of access to food retail provision in British cities: Studies of Cardiff, Leeds and Bradford. Urban Studies, 39, 11: 2041-2060.

Clarke, I., Hallsworth, A., Jackson, P., Kervenoael, R de., Perez-del-Aguila, R. and Kirkup, M. (2004) Retail competition and consumer choice: contextualising the "food deserts" debate. International Journal of Retail \& Distribution Management, 32, 2: 89-99.

Competition Commission (2000) Supermarkets: a report on the supply of groceries from multiple stores in the United Kingdom. The Stationery Office, Norwich.

Cummins, S. and Macintyre, S. (1999) The location of food stores in urban areas: a case study of Glasgow, British Food Journal, 101, 7: 545-553

Cummins, S. and Macintyre, S. (2002a) "Food deserts" - evidence and assumption in health policy making. British Medical Journal, 325, 7361: 436-438.

Cummins, S. and Macintyre, S. (2002b) A systematic study of an urban foodscape: the price and availability of food in Greater Glasgow, Urban Studies, 39, 11: 21152130.

Cummins, S., Petticrew, M., Higgins, C., Sparks, L. and Findlay, A. (2004) Reducing inequalities in health and diet: the impact of a food retail development: A pilot study. Report available from the Department of Health, August.

Cummins, S., Petticrew, M., Sparks, L. and Findlay, A. (2005a) Do large scale food retail interventions improve diet and health? British Medical Journal, 330: 683 - 684.

Cummins, S., Petticrew, M., Higgins, C, Sparks, L and Findlay, A. (2005b) Largescale food retailing as an intervention for diet and health: quasi-experimental evaluation of a natural experiment. Journal of Epidemiology and Community Health (forthcoming)

Department of Health (1999a) Reducing health inequalities: an action report. London: Department of Health. 
Department of Health (1999b) Report of Policy Action Team 13: improving shopping access for people living in deprived neighbourhoods. London: Department of Health.

Department of Health (2003) The food and health action plan. Food and health problems: analysis for comment. London: Department of Health.

Department of Health (2004) Choosing health: making healthier choices easier. White Paper on Public Health, November. CM 6374. London: Department of Health. Available for download from

http://www.dh.gov.uk/PublicationsAndStatistics/Publications/PublicationsPolicyAnd Guidance/PublicationsPolicyAndGuidanceArticle/fs/en?CONTENT_ID=4094550\&c $\mathrm{hk}=\mathrm{aN5Cor}$

Dobie, A. (2004) Following in Harlem’s Footsteps. RICS Business, March, 14-18.

Donkin, S.J.M., Dowler,E.A.., Stevenson, S.J. and Turne,r S.A. (1999) Mapping access to food at a local level. British Food Journal, 101, 7: 554-564.

Donkin, S.J.M., Dowler, E.A., Stevenson, S.J. and Turner, S.A., (2000) Mapping access to food in a deprived area: the development of price and availability. Public Health Nutrition, 3, 31-38

Donnison, D. and Middleton, A. (1987) Regenerating the inner city: Glasgow's experience. London: Routledge.

East, R., Hammond, K., Harris, P. and Lomax, W. (2000) First-store loyalty and retention, Journal of Marketing Management, 16: 307-325.

Furey, S., Strugnell, C. and McIlveen, H. (2001) An investigation of the potential existence of 'food deserts' in rural and urban areas of Northern Ireland. Agriculture and Human Values 18, 447-57.

Glasgow City Council and Strathclyde Regional Council (1993) Parkhead Forge impact study. Glasgow: Glasgow City Council.

Glasgow City Council (1992) Shopping policy review. Glasgow: Glasgow City Council

Grocer (2001) The regeneration game. The Grocer, 19/5/01, 36-46.

Guy, C. (2002) Arid debates. Town and Country Planning, 71, 10: 246-247.

Guy, C. (2004) Game on. Town and Country Planning, 73, 1: 10-11.

Guy, C. and David, G. (2004) Measuring physical access to 'healthy foods' in areas of social deprivation: a case study in Cardiff. International Journal of Consumer Studies, 28, 3: 222-234. 
Guy, C. and Duckett, M. (2003) Small retailers in an inner city community: a case study of Adamstown, Cardiff, International Journal of Retail and Distribution Management, 31, 8: 401-407.

Guy, C., Clarke, G. and Eyre, H. (2004) Food retail change and the growth of food deserts: a case study of Cardiff. International Journal of Retail \& Distribution Management, 32, 2: 72-88.

International Journal of Retail and Distribution Management (2004) Special Issue Extending the Food Desert Debate. International Journal of Retail \& Distribution Management, 32, 2: 72-136.

Kayani, N. (2003) Food Deserts: a practical guide. London: Chadwick House Publishing.

Lang, T. and Caraher, M. (1998) Access to healthy foods: Part II. Food poverty and shopping deserts: what are the implications for health promotion policy and practice? Health Education Journal, 57: 202-211.

NHS Health Scotland. Constituency health and well-being profiles 2004 Springburn, Shettleston. Downloaded from www.healthscotland.com/profiles on the $10^{\text {th }}$ June 2004.

Pacione, M. (1982) Retail redevelopment in the inner city: a case study of Springburn, Glasgow. Scottish Geographical Magazine, 98, 3: 166-179.

Rex, D. and Blair, A. (2003) Unjust des(s)erts: food retailing and neighbourhood health in Sandwell. International Journal of Retail \& Distribution Management, 31, 9: 459-465.

Scotland on Sunday (2002) Rotting Borough. Scotland on Sunday, 17 March 2002, 18.

Social Exclusion Unit (1998) Bringing Britain together: a national strategy for neighbourhood renewal. London: Stationery Office.

Social Exclusion Unit (2000) National strategy for neighbourhood renewal: policy action team audit. London: Cabinet Office.

Tesco Stores Ltd (2002a) Tesco Regeneration Partnerships Evaluation report 07:9906:02 - the story so far. Tesco Stores Ltd, Cheshunt

Tesco Stores Ltd (2002b) Tesco Regeneration Partnerships - the story so far. Tesco Stores Ltd, Cheshunt

Tesco Stores Ltd (2002c) St Rollox Partnership Evaluation report 06:02 - creating a better place to live and work. Tesco Stores Ltd, Cheshunt 
Tingay, R.S., Tan, C.J., Tan, N. C.-W., Tang, S., Teoh, P.H., Wong, R. and Gulliford, M.C.(2003) Food insecurity and low income in an English inner city. Journal of Public Health Medicine, 25, 2, 156-159.

Urban Studies (2002) Special Topic: 'Food Deserts' in British Cities. Urban Studies, 39, 11: 2029-2130.

Wanless, D. (2004) Securing good health for the whole population. Report for HM Treasury. Available for download from http://www.hmtreasury.gov.uk/consultations_and_legislation/wanless/consult_wanless04_final.cfm

Whelan, A., Wrigley, N., Warm, D. and Cannings, E. (2002) Life in a 'food desert'. Urban Studies, 39, 11: 2083-2100.

White, M., Bunting, J., Williams, L., Raybould, S., Adamson, A., Mathers, J. (2004) Do 'Food deserts' exist? A multi-level, geographical analysis of the relationship between retail food access, socio-economic position and dietary intake. Project Report N09010, available from the Food Standards Agency.

Wrigley, N. (2002) 'Food deserts' in British cities: Policy context and research priorities. Urban Studies, 39, 11: 2029-2040.

Wrigley, N., Guy, C. and Lowe, M. (2002) Urban regeneration, social inclusion and large store development: The Seacroft development in context. Urban Studies, 39 (11): 2101-2114.

Wrigley, N., Warm, D., Margetts, B. and Whelan, A. (2002) Assessing the impact of improved retail access on diet in a 'food desert': A preliminary report. Urban Studies, 39, 11: 2061-2082.

Wrigley, N., Warm, D. and Margetts, B. (2003a) Deprivation, diet and food retail access: findings from the Leeds 'Food Deserts' study. Environment and Planning A, 35, 151-188.

Wrigley, N, Warm, D and Margetts, B. (2003b) Food deserts. Food Link News, 42: 89.

Yeung, H. W. (2005) Rethinking relational economic geography, Transactions of the Institute of British Geographers, 31, 1: 37-51. 
Table 1: Retail Change in Springburn and Shettleston, 2001-2003

\begin{tabular}{|c|c|c|c|c|c|c|c|c|}
\hline & \multicolumn{2}{|c|}{$\begin{array}{c}\text { Springburn } \\
\text { October } 2001 \\
\end{array}$} & \multicolumn{2}{|c|}{$\begin{array}{c}\text { Shettleston } \\
\text { October } 2001\end{array}$} & \multicolumn{2}{|c|}{$\begin{array}{c}\text { Springburn May } \\
2003 \\
\end{array}$} & \multicolumn{2}{|c|}{$\begin{array}{c}\text { Shettleston May } \\
2003 \\
\end{array}$} \\
\hline & $\begin{array}{l}\text { Numb } \\
\text { er of } \\
\text { shops }\end{array}$ & $\%$ & $\begin{array}{l}\text { Numb } \\
\text { er of } \\
\text { shops }\end{array}$ & $\%$ & $\begin{array}{l}\text { Numb } \\
\text { er of } \\
\text { shops }\end{array}$ & $\%$ & $\begin{array}{l}\text { Numb } \\
\text { er of } \\
\text { shops }\end{array}$ & $\%$ \\
\hline Convenience & 67 & 36.0 & 94 & 31.5 & 67 & 36.0 & 89 & 30.2 \\
\hline Comparison & 29 & 15.6 & 52 & 17.4 & 30 & 16.1 & 49 & 16.6 \\
\hline Service & 58 & 31.2 & 100 & 33.6 & 68 & 36.6 & 108 & 36.6 \\
\hline Vacant & 32 & 17.2 & 52 & 17.4 & 21 & 11.3 & 49 & 16.6 \\
\hline Total Retail & 186 & 100.0 & 298 & 100.0 & 186 & 100.0 & 295 & 100.0 \\
\hline Total Stock* & 205 & & 315 & & 206 & & 316 & \\
\hline
\end{tabular}

*Includes shop units being used for quasi and non-retail uses (e.g. betting shops, offices etc.) 
Table 2 The Impact of Large-scale Retail Change on Retail Structure October 2001-May 2003

\begin{tabular}{|c|c|c|c|c|c|}
\hline \multicolumn{6}{|c|}{$\begin{array}{l}\text { A. Do retail stores impact positively or negatively on the existing retail } \\
\text { structure? }\end{array}$} \\
\hline & & & Springburn & Shettleston & $\begin{array}{l}\text { Comments on nature of } \\
\text { impact }\end{array}$ \\
\hline \multirow{2}{*}{$\begin{array}{l}\text { Vacancy } \\
\text { rates }\end{array}$} & \multicolumn{2}{|c|}{2001} & $17.2 \%$ & $17.4 \%$ & \multirow{2}{*}{$\begin{array}{l}\text { Positive impact on retail } \\
\text { property market of } \\
\text { regeneration }\end{array}$} \\
\hline & \multicolumn{2}{|c|}{2003} & $11.3 \%$ & $16.6 \%$ & \\
\hline \multicolumn{3}{|c|}{$\begin{array}{l}\text { \% change in vacant units } \\
2001-2003\end{array}$} & $-34.4 \%$ & $-5.8 \%$ & $\begin{array}{l}\text { Substantial differential in the } \\
\text { two areas. Significant effect } \\
\text { in Springburn }\end{array}$ \\
\hline \multirow{3}{*}{$\begin{array}{l}\text { Turnover } \\
\text { of stock by } \\
6 \text { month } \\
\text { period }\end{array}$} & \multicolumn{2}{|c|}{ 2001-2002 } & $4.8 \%$ & $7.6 \%$ & \multirow{3}{*}{$\begin{array}{l}\text { 'Churn' in both areas but } \\
\text { falls in Springburn to a lower } \\
\text { rate than Shettleston. }\end{array}$} \\
\hline & \multicolumn{2}{|c|}{$2002-2002$} & $6.2 \%$ & $7.9 \%$ & \\
\hline & \multicolumn{2}{|c|}{$2002-2003$} & $3.3 \%$ & $5.1 \%$ & \\
\hline \multicolumn{3}{|c|}{ Extension of food outlets } & 4 & 1 & $\begin{array}{l}\text { Smaller food outlets expand } \\
\text { into adjacent property }\end{array}$ \\
\hline \multicolumn{3}{|c|}{$\begin{array}{l}\text { New units (excluding } \\
\text { Tesco) }\end{array}$} & 2 & 2 & $\begin{array}{l}\text { Springburn units were new } \\
\text { build. }\end{array}$ \\
\hline \multirow{2}{*}{\multicolumn{2}{|c|}{$\begin{array}{l}\text { Stock becoming } \\
\text { vacant and } \\
\text { remaining vacant } \\
\text { for more than } 6 \\
\text { months }\end{array}$}} & 2001 & $4.8 \%$ & $5.1 \%$ & \multirow{2}{*}{$\begin{array}{l}\text { Residual stock unsuited to } \\
\text { modern retailing in both } \\
\text { areas }\end{array}$} \\
\hline & & 2003 & $1.9 \%$ & $1.9 \%$ & \\
\hline \multicolumn{3}{|c|}{$\begin{array}{l}\text { Stock going out of retail } \\
\text { sector 2001-2003 }\end{array}$} & $0 \%$ & $-2 \%$ & $\begin{array}{l}\text { Vitality of retail property } \\
\text { market in Springburn }\end{array}$ \\
\hline \multirow{2}{*}{\multicolumn{2}{|c|}{$\begin{array}{l}\text { Number of } \\
\text { vacant units in } \\
\text { prime locations* }\end{array}$}} & 2001 & 3 & 24 & \multirow{2}{*}{$\begin{array}{l}\text { No significant adverse effect } \\
\text { on the centre of Springburn }\end{array}$} \\
\hline & & 2003 & 4 & 23 & \\
\hline \multicolumn{6}{|c|}{$\begin{array}{l}\text { B. Do large retail stores increase or merely redistribute retail provision? Do they } \\
\text { represent improved food choice? }\end{array}$} \\
\hline \multicolumn{3}{|c|}{$\begin{array}{l}\text { Change in convenience } \\
\text { sector 2001-2003 }\end{array}$} & $0 \%$ & $-5.3 \%$ & $\begin{array}{l}\text { No adverse effect from } \\
\text { Tesco Springburn }\end{array}$ \\
\hline \multicolumn{3}{|c|}{$\begin{array}{l}\text { Change in comparison } \\
\text { sector 2001-2003 }\end{array}$} & $3.4 \%$ & $-5.8 \%$ & $\begin{array}{l}\text { Positive in Springburn but } \\
\text { declining in Shettleston }\end{array}$ \\
\hline \multicolumn{3}{|c|}{$\begin{array}{l}\text { Change in service sector } \\
\text { 2001-2003 }\end{array}$} & $17.2 \%$ & $8 \%$ & $\begin{array}{l}\text { Both areas increasing but } \\
\text { faster in Springburn }\end{array}$ \\
\hline \multicolumn{3}{|c|}{$\begin{array}{l}\text { Change in general stores } \\
\text { and CTNs 2001-2003 }\end{array}$} & 0 & 0 & No change \\
\hline \multicolumn{3}{|c|}{$\begin{array}{l}\text { Change in butchers } \\
\text { 2001-2003 }\end{array}$} & 0 & -1 & $\begin{array}{l}\text { No adverse impact on } \\
\text { Spingburn }\end{array}$ \\
\hline \multicolumn{3}{|c|}{$\begin{array}{l}\text { Change in fruit and } \\
\text { vegetable stores 2001- } \\
2003\end{array}$} & 0 & -1 & $\begin{array}{l}\text { No adverse impact on } \\
\text { Springburn }\end{array}$ \\
\hline
\end{tabular}

*Defined as Springburn Way and Shettleston Road respectively for Springburn and Shettleston 
Table 3: Outcome of a Large Scale Retail Intervention in Springburn: Policy Implications

\begin{tabular}{|c|c|c|}
\hline Policy & Possible Outcomes & Research Findings \\
\hline \multicolumn{3}{|l|}{ Health Agenda } \\
\hline Acheson report & $\begin{array}{l}\text { Combat diet related health } \\
\text { inequalities }\end{array}$ & $\begin{array}{l}\text { Not found (Cummins et al. } \\
\text { 2005a) }\end{array}$ \\
\hline $\begin{array}{l}2004 \text { White Paper } \\
\text { on Public Health }\end{array}$ & $\begin{array}{l}\text { Healthier choices for } \\
\text { disadvantaged groups and } \\
\text { local access to fruit and } \\
\text { vegetables in deprived } \\
\text { communities }\end{array}$ & $\begin{array}{l}\text { New provision has materially } \\
\text { increased food choice and } \\
\text { better access to fruit and } \\
\text { vegetables. Switching to the } \\
\text { store suggests it is } \\
\text { economically accessible. Also } \\
\text { evidence of more walking } \\
\text { trips to the store. }\end{array}$ \\
\hline \multicolumn{3}{|l|}{ Planning Agenda } \\
\hline NPPG8/PPG6 & $\begin{array}{l}\text { Restrictions on sites for } \\
\text { superstores }\end{array}$ & $\begin{array}{l}\text { Brownfield site redeveloped } \\
\text { by Tesco }\end{array}$ \\
\hline Regeneration & $\begin{array}{l}\text { Priority to regenerate deprived } \\
\text { areas, retailing one possible } \\
\text { catalyst }\end{array}$ & $\begin{array}{l}\text { Employment created at the } \\
\text { store and regeneration } \\
\text { occurring through new house } \\
\text { building, retailing a catalyst }\end{array}$ \\
\hline \multicolumn{3}{|l|}{ Social Policy } \\
\hline $\begin{array}{l}\text { Policy Action Team } \\
\text { on Shops }\end{array}$ & $\begin{array}{l}\text { Improvement local food } \\
\text { retailing and generate local } \\
\text { initiatives }\end{array}$ & $\begin{array}{l}\text { Large scale rather than local } \\
\text { initiative but boost to local } \\
\text { retailing }\end{array}$ \\
\hline \multicolumn{3}{|l|}{ Business strategy } \\
\hline $\begin{array}{l}\text { Retail store } \\
\text { expansion and } \\
\text { increased market } \\
\text { share }\end{array}$ & $\begin{array}{l}\text { Some areas left with poor } \\
\text { access to modern retail } \\
\text { facilities and a retail provision } \\
\text { deficit }\end{array}$ & $\begin{array}{l}\text { Tesco Partnership reduced } \\
\text { retail deficit and created } \\
\text { mainstream retail facility }\end{array}$ \\
\hline
\end{tabular}


Figure 1 Location of Springburn and Shettleston




Figure 2: Retail Units in the Intervention Area: Springburn

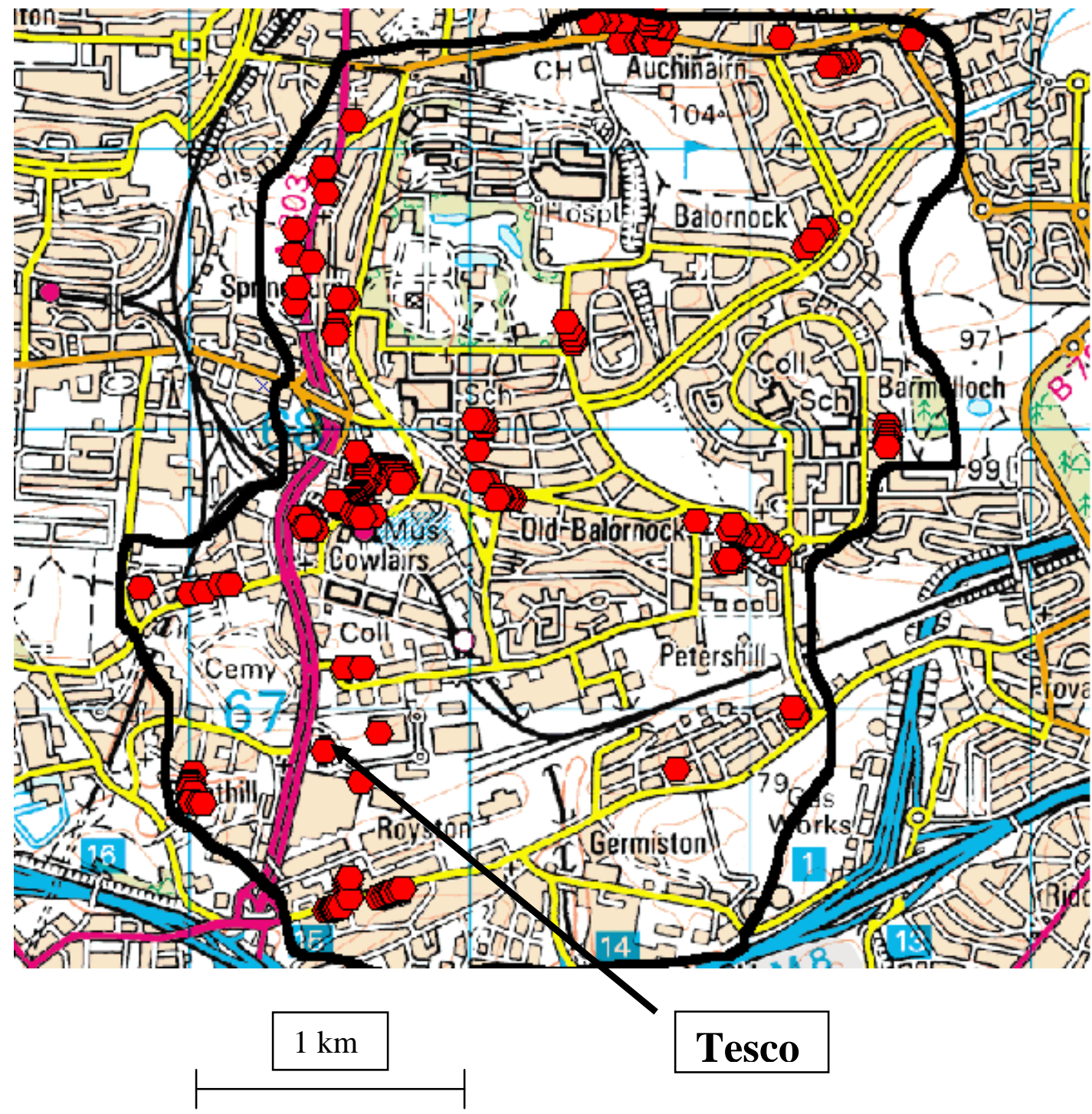

(C) Crown Copyright Ordnance Survey. An EDINA Digimap/JISC supplied service. 
Figure 3: Retail Units in the Control Area: Shettleston

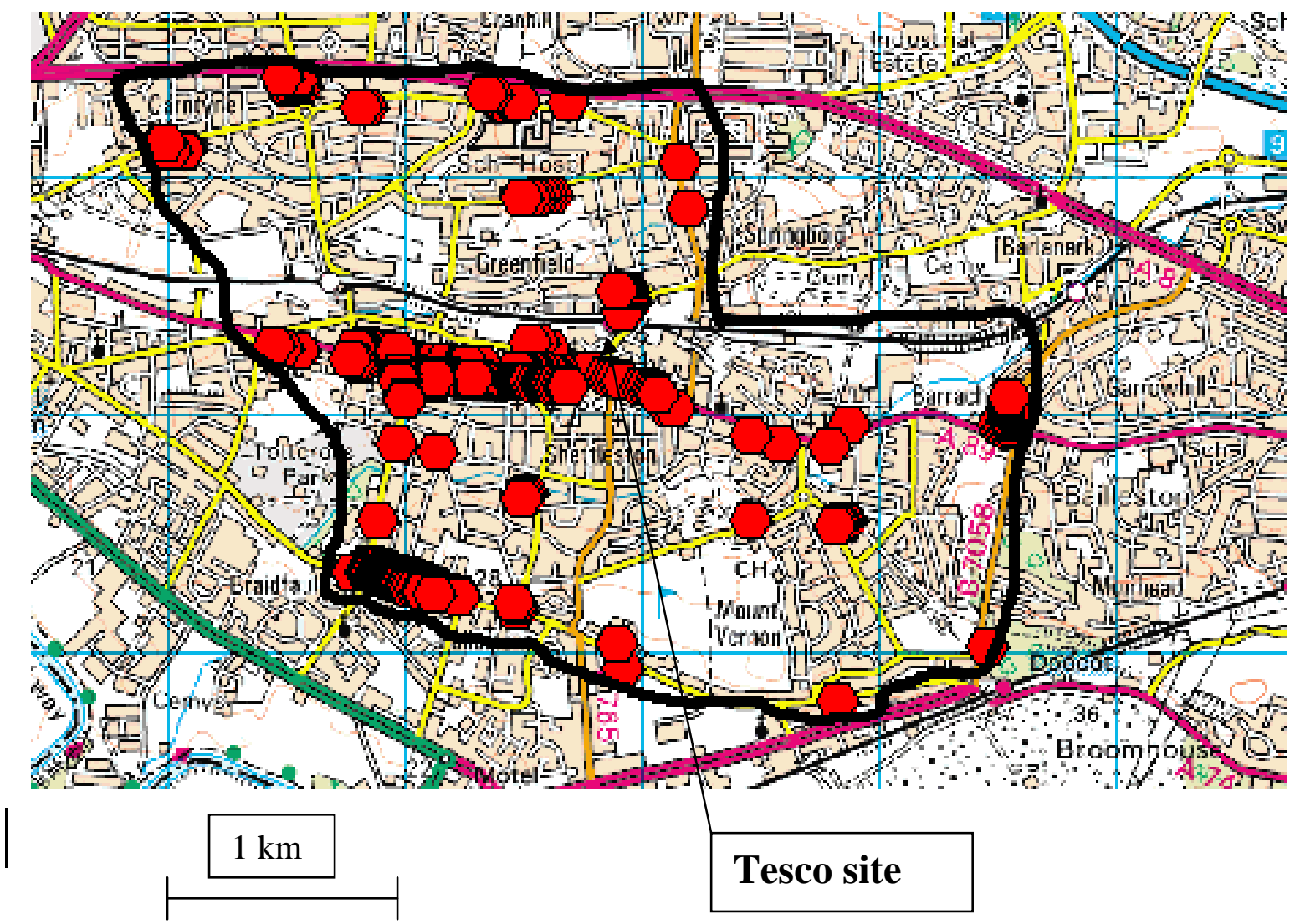

(C) Crown Copyright Ordnance Survey. An EDINA Digimap/JISC supplied service. 
Figure 4: Vacancy Rates in Springburn and Shettleston, 2001-4

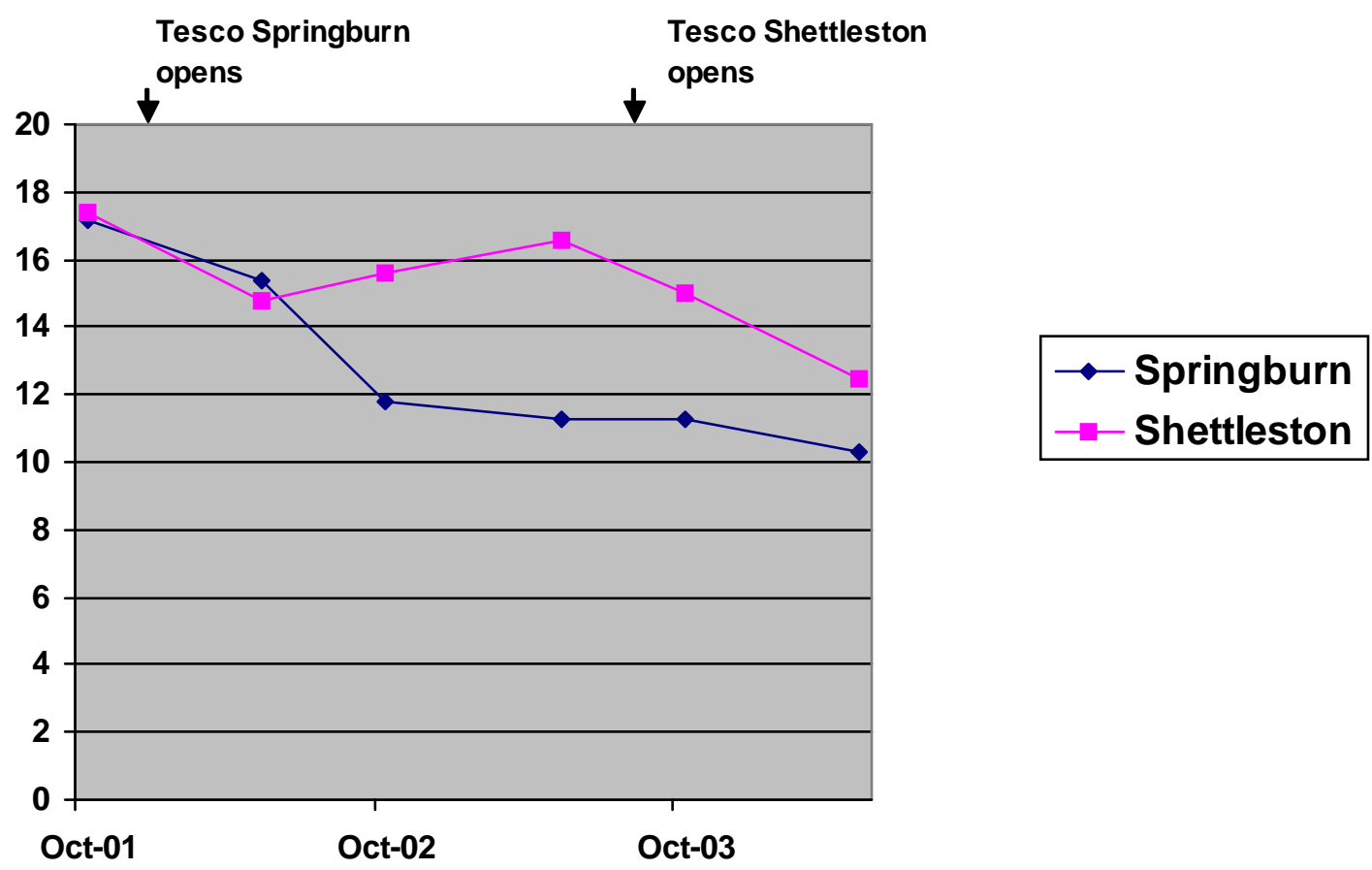

